\title{
Bedrii D. DEVELOPMENT OF A MODEL OF INTEGRATED RISK AND CONFLICT MANAGEMENT OF SCIENTIFIC PROJECT STAKEHOLDERS UNDER CONDITIONS OF BEHAVIORAL ECONOMY
}

Об’єктом дослідження є процеси управління конфліктами та ризиками стейкхолдерів наукового проекту, зокрема командою проекту, основними виконавиями проекту (науковиями) та іншими зацікавленими сторонами, в умовах поведінкової економіки. На сучасному етапі розвитку країни науковці працюють у дуже складних умовах, зокрема: обмеженості ресурсів (матеріальних, людських, фінансових, часових та інших). Складність внутрішніх та зовнішніх прощесів наукового проекту та взаємовідносин між його стейкхолдерами призводить до виникнення ризиків та конфліктів, що можуть бути викликані факторами поведінкової економіки. Тому необхідно системно підходити до аналізу зацікавлених сторін наукового проекту, розроблення єдиного підходу до інтегрованого управління ризиками та конфліктами стейкхолдерів наукового проекту в умовах поведінкової економіки.

У роботі запропоновано модель інтегрованого управління ризиками та конфліктами наукового проекту в умовах поведінкової економіки, яка грунтується на виконанні наступних етапів:

- проведення ідентифікацї стейкхолдерів та пов'язаних із ними ризиків, конфліктів та факторів поведінкової економіки, що можуть виникати в процесі планування та реалізацї наукового проекту й мати вплив на нього;

- побудова моделі інтегрованого управління ризиками та конфліктами стейкхолдерів наукового проекту в умовах поведінкової економіки;

- на основі ідентифікованих ризиків, конфліктів та факторів поведінкової економіки проведено моделювання інтегрованого управління ризиками та конфліктами стейкхолдерів наукового проекту в умовах поведінкової економіки.

Розроблена модель інтегрованого управління ризиками та конфліктами стейкхолдерів в умовах поведінкової економіки дозволить аналізувати основні фактори впливу стейкхолдерів, зокрема ризики, конфлікти та фактори поведінкової економіки, на науковий проект. Використання принципів інтегрованого управління різними факторами дозволяють визначити джерела та причини ускладнень, що можуть виникати в науковому проекті, а результати моделювання стануть у нагоді керівнику проекту та його команді в процесі планування та реалізації проекту.

Ключові слова: науковий проект, стейкхолдер, управління конфліктами та ризиками, фактор поведінкової економіки, інтегроване управління.

Received date: 02.02.2020

Accepted date: 13.03 .2020

Published date: 30.06 .2020
Copyright (C) 2020, Bedrii D. This is an open access article under the CC BY license (http://creativecommons.org/licenses/by/4.0)

\section{Introduction}

The project approach is successfully implemented in the world. Today, there are many different project management methodologies that provide effective and efficient tools for project management. The success of any project, including scientific, depends on meeting the needs and requirements of its stakeholders. Project stakeholder management includes the processes needed to identify people, groups, and organizations that may have an impact on the project and the project on them, to analyze their expectations and their impact on the project. In addition, the development of appropriate management strategies to effectively involve stakeholders in decision-making and project implementation [1, 2].

An important further development in this direction is the integration of various areas of management related to the im- pact of human resources and stakeholders, including risks, conflicts and behavioral factors of the stakeholders of the scientific project. This will ensure the successful completion of its implementation within the established time, budget and quality.

\section{The object of research and its technological audit}

The object of research is the processes of conflict and risk management of stakeholders of the scientific project, in particular the project team, the main executors of the project (scientists) and other stakeholders, in a behavioral economy.

In [3] the application of the project approach to the management of scientific activity was analyzed, in particular, its features and characteristics were identified, which allowed to provide a definition of the term «scientific 
project». In addition, [4] considered the factors of behavioral economics, which showed that human behavior in real life is significantly different from ideal rational behavior. Also, due to the fact that scientific projects are time-consuming, special attention should be paid to the identification of personnel risks of scientific projects that can lead to conflicts [5].

Every project, including a scientific one, has stakeholders who are affected by the project or can affect it in a positive or negative way. Therefore, the ability of the project manager to correctly identify and properly manage all stakeholders can determine the success or failure of the project. Thus, it is promising to develop effective and efficient tools for integrated risk and conflict management of a scientific project in a behavioral economy.

\section{The aim and objectives of research}

The aim of research is to develop of a model of integrated risk and conflict management of a scientific project under conditions of behavioral economy. This is aimed at ensuring the success of the scientific project within the established time, approved budget and obtaining a scientific product of appropriate quality. To achieve this aim it is necessary to complete the following objectives:

1. Identify stakeholders of scientific project and identification of personnel risks, conflicts and behavioral economics related to them.

2. Substantiate the need to integrate risk and conflict management of stakeholders in a behavioral economy.

3. Model the integration of risk, conflict and behavioral economics management associated with stakeholders of scientific project.

\section{Research of existing solutions of the problem}

The Project Management Knowledge Guide [1] provides recommendations for project management in general from the perspective of each individual area of knowledge, including risk management and stakeholders. And in [2] the individual competencies that are necessary for project, program and portfolio management are defined. But these documents do not have recommendations and requirements for conflict management and consideration of behavioral economics.

Many scientists have paid special attention to the study of human resources in any activity, including design. The paper [6] proposed the theory of stakeholders, which investigated that stakeholders have a significant impact on any activity, goal achievement and satisfaction of needs. This study examines in more detail the identification of stakeholders and the definition of their values, but risks, conflicts, and behavioral economics have not been considered.

In [7], the authors draw parallels between the technical and human components of project management and concluded that the main feature of a successful project is human resources, which can have both negative and positive effects on project implementation. Only risks and conflicts were highlighted, but behavioral factors were not taken into account.

The authors in $[8,9]$ proposed to take into account the creative and social components of man to ensure the success of activities and quality communication. This may be the basis for developing a new model of integrated management.

In works $[10,11]$ the complex methodology of risk management in any activity, in particular project, which can become a basis for the analysis of risks in scientific projects is resulted.

A new component of the project management methodology is proposed, in particular the conflict management of the scientific project [12], which includes the processes of project conflict management planning, conflict identification, conflict analysis, conflict response planning, conflict response and conflict monitoring. The implementation of these processes will allow the project manager and its team to take aware and controlled risk of project implementation in order to create value. This study can be considered in the process of integrating areas of project management knowledge such as risks and conflicts, taking into account the factors of behavioral economics.

The study of emotional intelligence as a driver of the development of breakthrough competencies in the project [13] is one of the factors of behavioral economics and can be taken into account in the process of identifying them in scientific projects.

In [14], modern approaches to the formation of «behavioral economy», its specifics in terms of decision-making processes in project management and anomalies that affect these processes. A meaningful model of diagnostics of application of models and methods of project management in «behavioral economy» is given. Patterns of behavior of project managers in project product creation and project management are studied. Such patterns will identify bottlenecks in the application of modern project management methodologies in a «behavioral economy».

Possibilities of applying the principles of behavioral economics in any field of activity, in particular in science, were analyzed in [4, 15] and found that irrational human behavior can lead to failure. In addition, behavioral economics factors were identified in $[16,17]$. These studies can be the basis for the identification of behavioral economics in scientific projects.

Thus, based on the results of the analysis of scientific works, it can be concluded that in most cases the successful implementation of the project and meeting the needs of its stakeholders depends on the skills and abilities of the project team. In addition, an important factor is the professional and competency and leadership qualities of the project manager, as well as its ability to avoid or prevent the impact of risks, conflicts and behavioral economics. Therefore, there is a need to develop a model of integrated risk and conflict management scientific project stakeholders taking into account the factors of behavioral economics.

\section{Methods of research}

It is assumed that the construction of a model of integrated risk and conflict management of a scientific project in a behavioral economy is based on the following stages:

1. Stakeholders and related risks, conflicts and behavioral factors that may arise in the planning and implementation of a scientific project and have an impact on it are identified.

2. Construct a model of integrated risk management and conflict scientific project stakeholders in terms of behavioral economics.

3. Based on the identified risks, conflicts and factors of behavioral economics, the modeling of integrated risk and conflict management of stakeholders of a scientific project in a behavioral economy is carried out.

Because the project management standard [1] contains detailed key concepts and considerations for the adaptation of project management processes, as well as for the use of 
tools and methods in project implementation. Therefore, it is necessary to integrate several areas of knowledge for more effective management of a scientific project. In addition, project management views the decision-maker as a rational person, but in today's world, scientists are increasingly paying attention to the study of irrational human behavior, in particular, acting in conditions of risk, uncertainty and conflict.

\section{Research results}

To build a model of integrated risk and conflict management of a scientific project in a behavioral economy, one of the first tasks is to identify stakeholders, risks, conflicts and behavioral economics factors related to their activities or inactions.

Stakeholder identification is the process of regularly identifying project stakeholders, as well as analyzing and documenting relevant information about their interests, involvement, interdependence, impact and potential impact on project success [1]. The results of stakeholder identification are given in Fig. 1.

The next step is to identify personnel risks of the scientific project. The complexity of personnel risk management is due to the fact that many types of personnel risks are not obvious, as they are related to human resources, which are based on the nature and essence of the individual, which is the most complex object of management $[5,10]$.

Thus, personnel risks are risks associated with the recruitment of project staff, involvement in certain types of work, organization of its work in a team, development, motivation and other areas of personnel work [10, 11]. Personnel risk management begins at the stage of project planning and human resource management of the project and covers all stages of the project life cycle $[1,5,11]$.

The sources of personnel risks include the external and internal environment of the project. The main causes of personnel risks are incomplete or inaccurate information, perception of information and the possibility of making the wrong decision by the manager or executor, lack or low level of staff involvement in the project $[1,5]$. Personnel risks arise as a result of manifestations of professional, business and personal qualities of the personnel of the enterprise and include such types as psychophysiological, personal, communicative, moral, educational, professional and qualification risks and risks of unreliability.

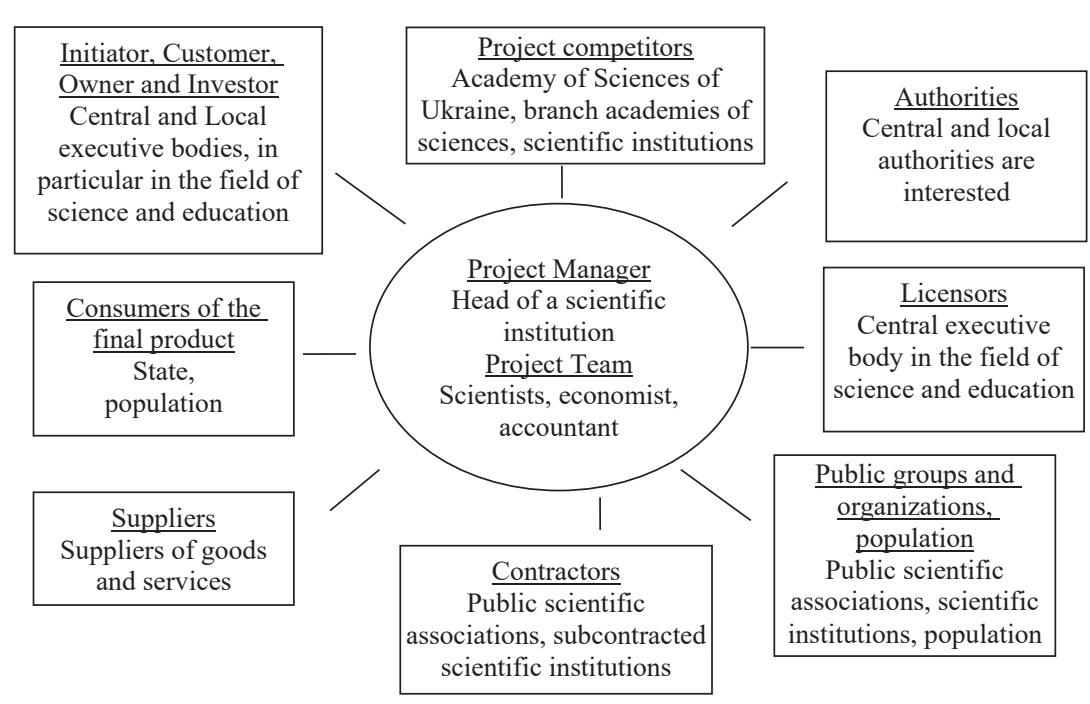

Fig. 1. Stakeholders of the scientific project
The results of identification of personnel risks of the scientific project are given in Table 1 [5].

Table 1

The general characteristics of personnel risks of the scientific project

\begin{tabular}{|c|l|l|}
\hline $\begin{array}{c}\text { Indication of the } \\
\text { group of person- } \\
\text { nel risks (R) }\end{array}$ & $\begin{array}{c}\text { Name of personnel } \\
\text { risk group }\end{array}$ & \multicolumn{1}{c|}{$\begin{array}{c}\text { Causes of the group } \\
\text { of personnel risks }\end{array}$} \\
\hline R1 & $\begin{array}{l}\text { Risks associated with } \\
\text { personnel policy }\end{array}$ & $\begin{array}{l}\text { Errors in the development of areas } \\
\text { of personnel management, insuf- } \\
\text { ficient justification of project pri- } \\
\text { orities, erroneous statement of the } \\
\text { project goal and inaccurate prouf } \\
\text { of specific tasks of the project staff }\end{array}$ \\
\hline R2 & $\begin{array}{l}\text { Risks associated with } \\
\text { staffing issues }\end{array}$ & $\begin{array}{l}\text { Errors in personnel selection, pro- } \\
\text { ject documentation development, } \\
\text { project timing and budget plan- } \\
\text { ning, insufficient staff qualifica- } \\
\text { tions, overload, fatigue and illness }\end{array}$ \\
\hline R3 & $\begin{array}{l}\text { Risks associated with } \\
\text { an ineffective system } \\
\text { of motivation and in- } \\
\text { centives }\end{array}$ & $\begin{array}{l}\text { Unsatisfactory working conditions, } \\
\text { unmet needs and goals, insuf- } \\
\text { ficient attention to professional } \\
\text { development, lack of tangible and } \\
\text { intangible incentives, compensa- } \\
\text { tion payments }\end{array}$ \\
\hline B4 & $\begin{array}{l}\text { Risks associated with } \\
\text { the confidentiality of in- } \\
\text { formation in the project }\end{array}$ & $\begin{array}{l}\text { Improper collection, disclosure or } \\
\text { use of confidential information } \\
\text { about the project }\end{array}$ \\
\hline
\end{tabular}

Using the tool proposed in [12], let's identify conflicts in a scientific project. The purpose of conflict management of a scientific project is to maximize the probability of its successful completion by increasing the probability of positive conflicts and strengthening their impact; reducing the likelihood of negative conflicts and weakening their impact. Based on this, the main types of conflicts are identified during the planning and implementation of scientific projects, which are given in Table 2 [18].

In order to reduce the impact of irrational behavior of stakeholders, it is proposed to apply the principles of behavioral economics in the management of scientific projects.

The study of behavioral economics is based on experimental observations, various types of research, surveys, testing, but recently increasingly used econometric analysis of data collected during field research [4, 15, 17].

Fundamental in the theory of behavioral economics is the rejection of the theory of traditional rational behavior and analysis of the irrational component of the behavior of economic agents. After all, this requires understanding and studying the irrational grain behind human feelings, thoughts and actions.

Based on all the research conducted, behaviorists conclude that people make all sorts of management decisions that do not always correspond to the model of rational choice.

Behaviorists suggest that by analyzing the psychological aspects of decision making, it is possible to predict behavioral errors that may be made by individuals and analyze the influence of mental states of individuals on their behavior in making important management decisions [15, 16].

The results of the identification of behavioral economics factors are given in Table 3. Risks, conflicts and behavior of any stakeholder of a scientific project, 
as well as any other, can lead to disruption of its implementation or to its timely and high-quality completion. Therefore, it is proposed to develop a model of integrated risk and conflict management of stakeholders in a behavioral economy, which are given in Fig. 2.
Based on the information, which are given in Fig. 1 and Tables $1-3$, it is possible to give correspondence of stakeholders and their risks, conflicts and factors of behavioral economy which can lead to failure of realization of the scientific project (Fig. 3).

The main types of conflicts of the scientific project

Table 2

\begin{tabular}{|c|c|c|}
\hline $\begin{array}{l}\text { Indication of the } \\
\text { type of conflict (K) }\end{array}$ & Types of conflicts & The essence of the conflict \\
\hline K1 & $\begin{array}{l}\text { Conflicts arising due to personal } \\
\text { relationships }\end{array}$ & $\begin{array}{l}\text { Where decision-makers have a personal relationship with those affected (family members, relatives, } \\
\text { friends), participation should be avoided to ensure objectivity and limit the impact of personal rela- } \\
\text { tionships (both positive and negative interests) in making these decisions. The main cause of these } \\
\text { conflicts in scientific teams is the succession of positions, including management }\end{array}$ \\
\hline $\mathrm{K2}$ & $\begin{array}{l}\text { Conflicts arising due to holding } \\
\text { several positions (roles) in the } \\
\text { scientific team }\end{array}$ & $\begin{array}{l}\text { Such conflicts of interest (real, potential and imaginary) can be resolved by avoiding a decision that } \\
\text { could interfere with balanced, objective judgments and conclusions, such as drawing collegial atten- } \\
\text { tion to possible bias and bias }\end{array}$ \\
\hline $\mathrm{K3}$ & $\begin{array}{l}\text { Conflicts arising due to the use of } \\
\text { resources of a scientific institution }\end{array}$ & $\begin{array}{l}\text { In case the goals and objectives of the scientific project and an individual member of its team coin- } \\
\text { cide (for example, a scientific publication, an analytical note, etc.), the project resources can be used. } \\
\text { In other cases, this may cause conflict in the scientific project team }\end{array}$ \\
\hline K4 & $\begin{array}{l}\text { Conflicts arising due to material } \\
\text { and financial interests }\end{array}$ & $\begin{array}{l}\text { Members of the scientific project team, using intellectual property rights, have the right to enter into } \\
\text { agreements and freely sell their works created in the framework of their scientific activities, without } \\
\text { causing a conflict of interest, as long as it does not interfere with basic responsibilities }\end{array}$ \\
\hline K5 & $\begin{array}{l}\text { Conflicts arising due to involve- } \\
\text { ment in activities outside the main } \\
\text { scientific institution }\end{array}$ & $\begin{array}{l}\text { Recently, scientific teams and their individual scientists are increasingly cooperating and have business } \\
\text { relationships with various public institutions and the private sector, with public and private research } \\
\text { foundations that support their research and use knowledge and experience. Such cooperation is } \\
\text { socially and economically profitable and profitable }\end{array}$ \\
\hline K6 & $\begin{array}{l}\text { Conflicts of obligations that arise } \\
\text { in relation to the ratio of time } \\
\text { spent and responsibilities and ob- } \\
\text { ligations in the scientific institution }\end{array}$ & $\begin{array}{l}\text { This type of conflict can arise when the activity outside the scientific institution intersects with the } \\
\text { activity in it and interferes with the fulfillment of obligations at the main place of work. The main } \\
\text { problem of these conflicts is the deterioration of the moral and psychological state of the scientist, in } \\
\text { particular, they can lead to fatigue, a state of constant stress, reduced efficiency }\end{array}$ \\
\hline
\end{tabular}

Factors of behavioral economics in the management of the scientific project*

Table 3

\begin{tabular}{|c|c|c|}
\hline $\begin{array}{c}\text { Indication of } \\
\text { the factor }(\mathrm{BEF})\end{array}$ & $\begin{array}{l}\text { The name } \\
\text { of the factor }\end{array}$ & The essence of the factor \\
\hline BEF1 & $\begin{array}{l}\text { Epistemic } \\
\text { self-confidence }\end{array}$ & $\begin{array}{l}\text { A person's reluctance to acknowledge that human knowledge is limited, in particular: people overestimate their } \\
\text { knowledge and underestimate uncertainty, narrowing the range of possible uncertain situations, so many people } \\
\text { tend to «tunnel» and "narrow» thinking }\end{array}$ \\
\hline BEF2 & «Anchoring» & $\begin{array}{l}\text { Making management decisions on the basis of the first received data, in particular there is a consciously or uncon- } \\
\text { sciously established strong conditioned-reflex connection }\end{array}$ \\
\hline BEF3 & $\begin{array}{l}\text { Dunning-Кгueger } \\
\text { effect }\end{array}$ & $\begin{array}{l}\text { Making wrong decisions by incompetent people who are not able to realize it due to too much confidence in their } \\
\text { own knowledge and competence }\end{array}$ \\
\hline BEF4 & Procrastination & $\begin{array}{l}\text { Postponement of cases «for later», as a rule, the most difficult cases, which has negative consequences - not done } \\
\text { on time and negative destructive emotions - guilt, shame, anger }\end{array}$ \\
\hline BEF5 & Emotional condition & $\begin{array}{l}\text { It can have a great influence on a person's choice, in particular: in psychologically "hot» states, such as anger, fear, } \\
\text { admiration, excitement, etc., individuals are able to make ill-considered decisions. On the contrary, in «cold» states - } \\
\text { calm, composure, sober reflection, etc. - a person is able to make informed decisions }\end{array}$ \\
\hline BEF6 & $\begin{array}{l}\text { Mistakes } \\
\text { of optimism and } \\
\text { pessimism }\end{array}$ & $\begin{array}{l}\text { The mistake of optimism makes people overconfident when making decisions. Its essence is in underestimating } \\
\text { the probability of occurrence of undesirable events that can cause serious, very irreparable damage to a person. } \\
\text { There is an opposite mistake - pessimism, which makes people the most insecure, forcing them to exaggerate the } \\
\text { likelihood of adverse events }\end{array}$ \\
\hline BEF7 & $\begin{array}{l}\text { «Illusion } \\
\text { of objectivity» }\end{array}$ & $\begin{array}{l}\text { Subconscious bias is present in everyone and very often it contradicts the proclaimed values. Man, even on the } \\
\text { basis of the best motivations, in the decision-making process is influenced by unconscious thoughts and feelings }\end{array}$ \\
\hline BEF8 & Perfectionism & $\begin{array}{l}\text { Confidence in the possibility of achieving the best result, the desire to bring each action to excessively high results, } \\
\text { scrupulousness, concentration on mistakes, doubts about the quality of work tasks; susceptibility to criticism, im- } \\
\text { balance in self-esteem and others }\end{array}$ \\
\hline BEF9 & Conflict of interest & $\begin{array}{l}\text { A situation in which the employee's personal interest may influence the decision-making process and cause damage } \\
\text { to the interests of the company or company that is the employee's employer }\end{array}$ \\
\hline BEF10 & $\begin{array}{l}\text { Excessive funding } \\
\text { of tasks }\end{array}$ & $\begin{array}{l}\text { Making the wrong or ill-considered decision by any participant of the scientific project on the expenditure of available } \\
\text { funds for tasks that are not of strategic importance, but are important for implementation, at the stage of current work }\end{array}$ \\
\hline BEF11 & $\begin{array}{l}\text { Revaluation of } \\
\text { monetary resources }\end{array}$ & $\begin{array}{l}\text { Overestimation of necessary resources by any participant of the scientific project at the request for financing of each } \\
\text { separate task of the project }\end{array}$ \\
\hline BEF12 & Scattering goals & Diversion or distraction of the participants of the scientific project from the strategic goals of the project \\
\hline BEF13 & $\begin{array}{l}\text { Unproductive } \\
\text { communications }\end{array}$ & $\begin{array}{l}\text { Impossibility for any project participant to find a common language with others in the process of its planning and } \\
\text { implementation. Non-implementation of the communication plan in the scientific project, which may contribute to the } \\
\text { failure of the project and the emergence of risks, uncertainty and conflict }\end{array}$ \\
\hline BEF14 & Egocentrism & $\begin{array}{l}\text { The focus of the project participant on their own goals, aspirations and experiences and the inability as a result to } \\
\text { perceive another person as a different person. Such behavior in a scientific project can lead to risks, uncertainty } \\
\text { and conflict, as well as loss of resources (human, material, time), failure to perform project work, etc. }\end{array}$ \\
\hline
\end{tabular}

Note: ${ }^{*}$ - built on data $[4,15-17]$ 


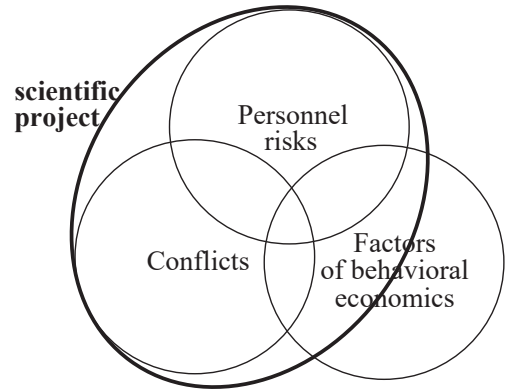

Fig. 2. Model of integrated risk and conflict management of scientific project stakeholders in a behavioral economy

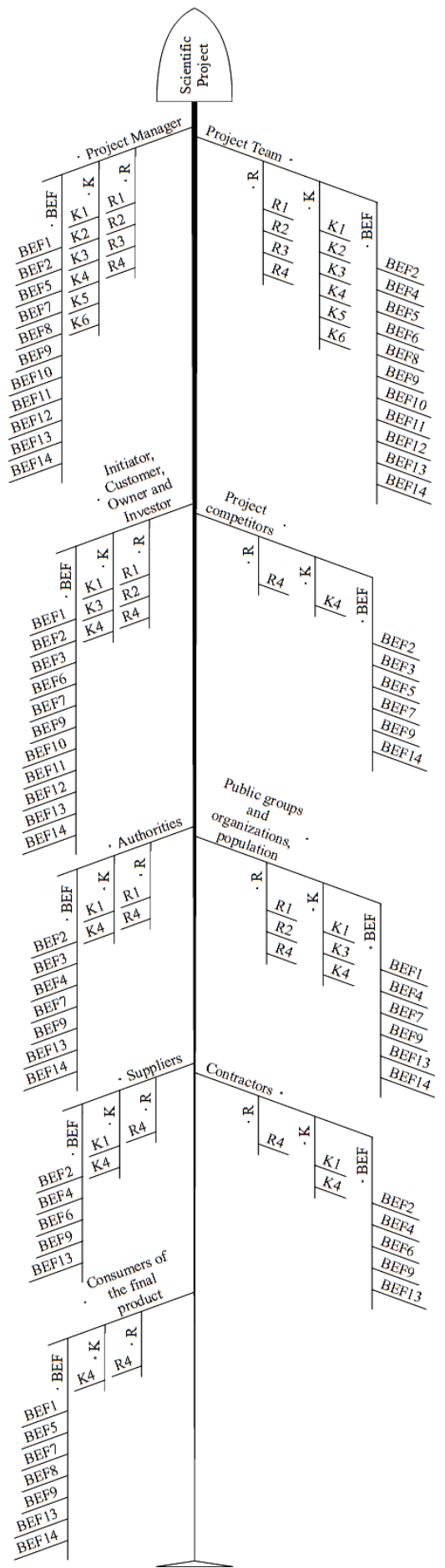

Fig. 3. Modeling of integrated risk and conflict management of scientific project stakeholders in a behavioral economy
The identification of scientific project stakeholders and their risks, conflicts and factors of behavioral economics made it possible to model the integrated risk and conflict management of scientific project stakeholders in a behavioral economy.

These results will be useful to the project manager and its team in the process of its planning and implementation.

\section{SWOT analysis of research results}

Strengths. The developed model of integrated risk and conflict management of stakeholders in a behavioral economy allows to analyze the main factors influencing stakeholders, including risks, conflicts and behavioral economics, on the scientific project.

The use of the principles of integrated management of various factors allows to determine the sources and causes of complications that may arise in the scientific project, and the simulation results will be useful to the project manager and its team in the process of planning and implementation.

Weaknesses. At this stage of the study there is no single approach to integrated risk management, conflict and behavioral economics of stakeholders of a scientific project, which would comprehensively characterize the success of such a project. Under certain conditions, this can complicate the identification and analysis of stakeholder impact.

Opportunities. The proposed model of integrated risk and conflict management of stakeholders in a behavioral economy allows the following:

- to identify the stakeholders of the scientific project and their risks, conflicts and behavioral economics at the planning stage;

- to determine the impact of risks, conflicts and behavioral economics factors on scientific project stakeholders, which will be the basis for developing a unified approach to integrated risk and conflict management of scientific project stakeholders in a behavioral economy.

Threats. Achieving the success of a scientific project is possible under the condition of integrated management of risks, conflicts and factors of behavioral economics.

\section{Conclusions}

1. Stakeholders in the scientific project and identified personnel risks, conflicts and related behavioral economics are identified. This approach allows to quickly analyze the main factors influencing the stakeholders of a scientific project at the planning stage.

2. The necessity of integration of risk and conflict management of stakeholders in the conditions of behavioral economy is substantiated. This will allow for comprehensive planning of risk, conflict and behavioral economics of stakeholders for the successful completion of a scientific project.

3. The integration of risk, conflict and behavioral economics management, which is related to the stakeholders of the scientific project, is modeled. As a result, a model of integrated risk and conflict management of scientific project stakeholders under conditions of behavioral economy is developed, which combined separate areas of project management knowledge. This result provides an effective tool for integrated management of risks, conflicts and behavioral economics of stakeholders, which will be useful in the process of studying the irrational behavior of stakeholders of any project. 


\section{References}

1. A Guide to the Project Management Body of Knowledge (2017) $\mathrm{PMBOK}^{\circledR}$ Guide, PMI, 574.

2. International Project Management Association (2015). Individual Competence Baseline for Project, Programme \& Portfolio Management, 415.

3. Bedrii, D. I. (2017). Osoblyvosti proektno-oriientovanoho upravlinnia naukovymy proektamy. Project, Program, Portfolio Management. Odesa: ONPU, 2, 15-18.

4. Bedrii, D. I. (2019). Ohliad faktoriv povedinkovoi ekonomiky v upravlinni naukovymy proektamy. Project, Program, Portfolio Management. Odesa: ONPU, 1, 14-18.

5. Danchenko, O. B., Bedrii, D. I., Semko, I. B. (2017). Identyfikatsiia kadrovykh ryzykiv naukovykh proektiv. Upravlinnia proektamy ta rozoytok vyrobnytstva, 4 (64), 18-24.

6. Freeman, R. E., Harrison, J. S., Wicks, A. C., Parmar, B. L., de Colle, S. (2010). Stakeholder Theory: The State of the Art. Cambridge University Press, 300. doi: http://doi.org/10.1017/ cbo9780511815768

7. Demarko, T., Lister, T. (2005). Chelovecheskii faktor: uspeshnye proekty i komandy. Saint Petersburg: Simvol-Plius, 200.

8. Strack, R., Caye, J.-M., Carsten von der Linden, Haen, P., Abramo, F. (2013). Creating People Advantage. Lifting HR Practices to the Next Level. Available at: https://image-src.bcg.com/ Images/Creating People Advantage Oct 2013 tcm9-91995.pdf

9. Dayton, D. (2011). Communicating quality: the social construction of management and leadership. Mason: ALEF Consulting.

10. Smith, P. G., Merritt, G. M. (2002). Proactive risk management. New York: Productivity Press, 246.

11. Thamhain, H. (2013). Managing Risks in Complex Projects Project Management Journal, 44 (2), 20-35. doi: http://doi.org/ 10.1002/pmj.21325
12. Danchenko, O. B., Bedrii, D. I., Semko, I. B. (2019). Conflict management of scientific project. Bulletin of NTU «KhPI». Series: Strategic Management, Portfolio, Program and Project Management, 2 (1327), 28-35. doi: http://doi.org/10.20998/24133000.2019.1327.5

13. Bushuyev, S., Bushuiev, D. (2017). Emotional Intelligence - The Driver of Development of Breakthrough Competences of the Project. Proceedings 30th IPMA World Congress - Breakthrough competences for managing change. Astana, 8-14. doi: http:// doi.org/10.1109/stc-csit.2017.8099418

14. Bushuiev, S. D., Bushuiev, D. A., Yaroshenko, R. F. (2018) Upravlinnia proektamy v umovakh «povedinkovoi ekonomiky». Upravlinnia rozoytkom skladnykh system, 33, 22-30. Available at: http://urss.knuba.edu.ua/files/zbirnyk-33/5.pdf

15. Iakovleva, E. A. (2016). Analiz vozmozhnostei ispolzovaniia principov povedencheskoi ekonomiki dlia priniatiia effektivnykh upravlencheskikh reshenii. Sovremennye tekhnologii upravleniia, 5 (65). Available at: https://sovman.ru/article/6504/

16. Taleb, N. N. (2015). Chernii lebed. Pod znakom nepredskazuemosti. Moscow: KoLibri, 736.

17. Sepeda Huaman, D. F., Danchenko, O. B. (2019). Vdoskonalenyi metod PESTLE-analizu zovnishnoho seredovyshcha proektiv. Upravlinnia proektamy u rozoytku suspilstva. Upravlinnia proektamy $v$ umovakh ochikuvannia hlobalnykh zmin. Kyiv: KNUBA, 96-98.

18. Bedrii, D. I. (2018). Identyfikatsiia konfliktiv u naukovykh proektakh. Project, Program, Portfolio Management, 2, 17-20.

Bedrii Dmytro, PhD, Deputy Director for Scientific Work, State Enterprise «Ukrainian Scientific Research Institute of Radio and Television», Odesa, Ukraine,e-mail: dimi7928@gmail.com, ORCID: http:// orcid.org/0000-0002-5462-1588 